\title{
Author Correction: Enhanced oxygen reduction with single-atomic-site iron catalysts for a zinc-air battery and hydrogen-air fuel cell
}

Yuanjun Chen, Shufang Ji, Shu Zhao, Wenxing Chen, Juncai Dong $\mathbb{B}$, Weng-Chon Cheong, Rongan Shen, Xiaodong Wen, Lirong Zheng, Alexandre I. Rykov, Shichang Cai, Haolin Tang, Zhongbin Zhuang, Chen Chen, Qing Peng, Dingsheng Wang (i) \& Yadong Li

Correction to: Nature Communications https://doi.org/10.1038/s41467-018-07850-2, published online 21 December 2018. In this article the wrong figure appeared as Supplementary Figure 47; the figure should have appeared as shown below.
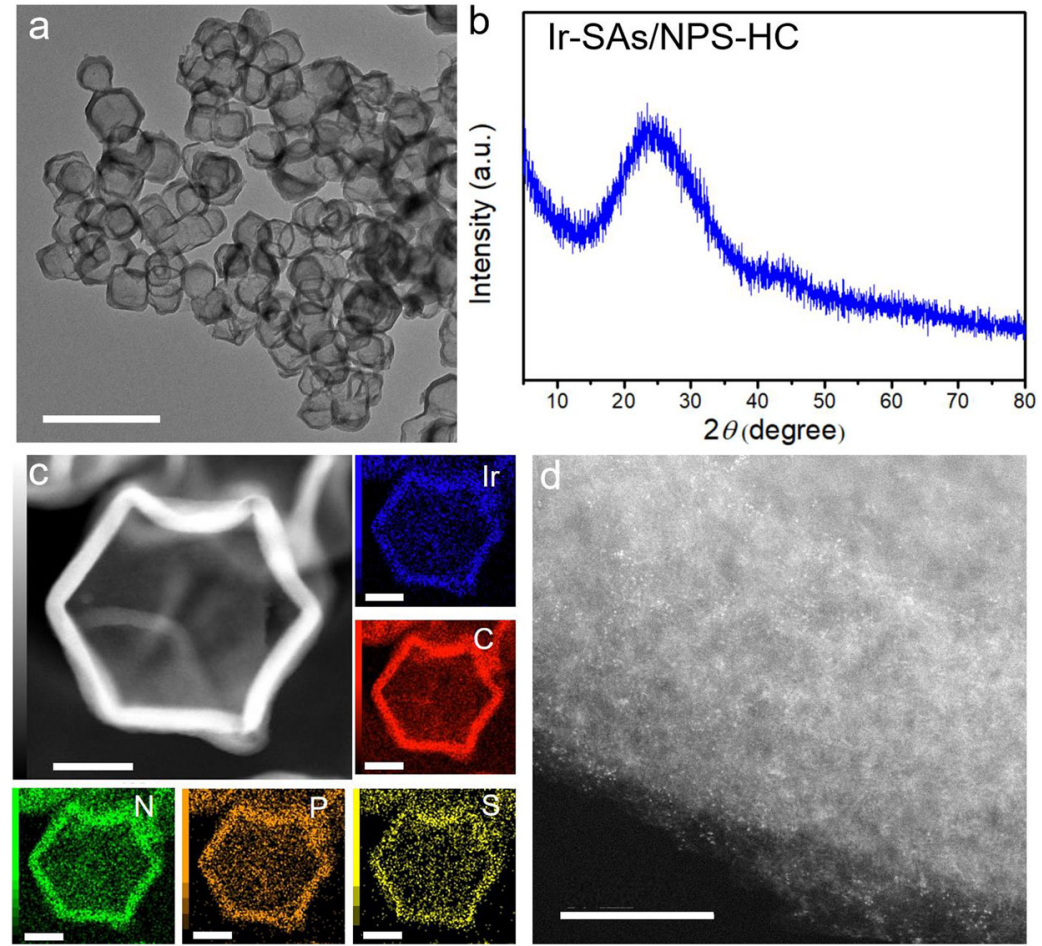

The original article has been corrected.

Published online: 11 February 2022 


\section{Additional information}

Supplementary information The online version contains supplementary material available at https://doi.org/10.1038/s41467-022-28495-2.

(c) Open Access This article is licensed under a Creative Commons Attribution 4.0 International License, which permits use, sharing, adaptation, distribution and reproduction in any medium or format, as long as you give appropriate credit to the original author(s) and the source, provide a link to the Creative Commons license, and indicate if changes were made. The images or other third party material in this article are included in the article's Creative Commons license, unless indicated otherwise in a credit line to the material. If material is not included in the article's Creative Commons license and your intended use is not permitted by statutory regulation or exceeds the permitted use, you will need to obtain permission directly from the copyright holder. To view a copy of this license, visit http://creativecommons.org/licenses/by/4.0/.

(c) The Author(s) 2022 